\title{
Productive, Qualitative, and Physiological Aspects of Layer Hens Fed with Propolis
}

\section{-Author(s)}

\section{Belloni M}

Almeida Paz ICL"

Nääs IA"

Alves MCFIII

Garcia RG"

Caldara FR"

Seno LO"

MSc in Animal Science, Assistant Professor, UNIGRAM, Dourados, MS, Brazil.

" Professor, FCA Universidade Federal da Grande Dourados. Dourados, MS, Brazil.

III MSc in Animal Science, FCA, Universidade Federal da Grande Dourados. Dourados, MS, Brazil.

\section{-Mail Address}

Corresponding author e-mail address Rodrigo G. Garcia

FCA, Universidade Federal da Grande Dourados. Dourados, Rod. Dourados

- Itahum, Km 12 - Cidade Universitaria,

Cx. Postal 533 - CEP 79804-970

67 3410-2001, MS, Brazil.

E-mail:rodrigogarcia@ufgd.edu.br

\section{EKeywords}

Egg production, infrared thermography, natural diet supplement.

\section{ABSTRACT}

Laying hens reared under tropical conditions are usually under heat stress. Propolis is known for its pharmaceutical properties, such as increasing cell tolerance to hyperthermia, because of its antioxidants effects. This study aimed at evaluating the influence of different dietary propolis inclusion levels on the performance, egg quality, and bird surface temperature of layers. In this experiment 120 55-wk-old Isa Brown ${ }^{\circledR}$ layers were distributed according to a completely randomized experimental design into four treatments $(0,1,2$ and $3 \%$ dietary propolis inclusion levels), with three replicates of ten birds each. Performance and egg quality parameters, and birds' surface temperature were evaluated. Egg production, egg mass, feed intake, and feed conversion ratio were influenced by the treatments. Bird surface temperature was not affected by propolis dietary inclusion. The egg yolk color changed with the treatment $(p<0.05)$ when brightness and red and yellow concentration were considered. Evaluators noted a slight difference among treatments during the sensory analysis. The use of propolis in the hens' diet did not improve performance and worsened the eggs' quality.

\section{INTRODUCTION}

Acute or chronic stress may significantly affect bird physiology, impairing their live performance and resistance to diseases. Stress factors include climate, environment, nutrition, diseases, as well as management practices, such as cage density and transport (Freeman, 1987).

Live performance and egg quality parameters are commonly used to evaluate the effects of rearing conditions on layers (Alves et al., 2007; Mustaf et al., 2008; Nääs et al., 2010). Worldwide, researchers have studied different types of feed additives to try to mitigate heat stress and to improve hen welfare (Garcia et al., 2002; Galal et al., 2008; Seven, 2008).

Propolis is a complex resinous mixture with dark-yellow to brown color. It is collected by bees from buds, leaves and other parts of trees, such like pines, oaks, eucalyptus, poplars, chestnut trees, Baccharis dracunculifolia, Tabuia sp., cashew tree (Anacardium occidentale, as well from other botanical sources, and mixed with wax. Propolis has anti-microbial, anti-inflammatory and antioxidant pharmacological properties (Nieva Moreno et al., 1999). Propolis, especially its compound CAPE (Caffeic Acid Phenethyl Ester), is used in research on heat stress mitigation, as it improves thermal tolerance (Chen et al., 2009). The antioxidant, cytostatic, antimutagenic, and immunomodulatory properties of propolis are based on its rich flavonoid, phenolic acid, and terpenoid contents (Kimoto et al., 1999; Wang et al., 2003). Current 
literature indicates that the inclusion of propolis in poultry diets might improve their immune status without influencing their weight gain or performance (Khojasteh \& Shivazad, 2006; Seven, 2008).

This study aimed at evaluating the effect of different dietary propolis inclusion levels on the performance, egg quality, and the surface temperature of layers.

\section{METHODOLOGY}

The study was carried out at the experimental layer house of the School of Agricultural Sciences, Federal University of Grande Dourados, MS, Brazil (latitude 22 - 11 'S and longitude $54^{\circ} 56^{\prime} \mathrm{W}$ ), from June 2011 to March 2012. The experimental procedures were approved by the Ethics Committee of the UFGD under protocol number 03/2012.

\section{Birds and husbandry}

A total of 120 55-wk-old Isa Brown ${ }^{\circledR}$ layers were randomly distributed into four treatments of 30 hens each. The following treatments were applied: no addition of propolis in the diet (T1, control), dietary addition of $1 \%$ propolis (T2), dietary addition of $2 \%$ propolis (T3), and dietary addition of 3\% propolis (T4). Each treatment included three replicates with ten hens.

Hens were kept in cages in a room with no environmental control, and the management adopted was that recommended by Isa Brown manual (2006). Birds were exposed to a lighting regimen of 17 of (natural and artificial) light in $24 \mathrm{~h}$. Water, and feed were offered ad libitum. Eggs were collected once daily.

The treatment diets were manufactured at the university feed mill. The basal diet was a typical layer diet, formulated to meet the nutrient requirements recommended by the National Research Council (NRC, 1994) and contained $2,750 \mathrm{kcal} / \mathrm{kg}$ metabolizable energy (ME), $16.50 \%$ crude protein, $4 \%$ calcium, $0.54 \%$ available phosphorus, $2.53 \%$ crude fiber, $0.3 \%$ methionine, $0.53 \%$ sulfur amino acids, and $0.8 \%$ lysine. The propolis powder was purchased from a commercial store, and its chemical analysis is shown in Table 1. Propolis was added to the on top of the feed.

\section{Estimated parameters}

The following performance parameters were analyzed: feed intake, feed conversion ratio per egg laid, and feed conversion ratio per egg mass. Data were registered and calculated weekly. Feed conversion ratio
Table 1 - Chemical analysis of the propolis powder added to the basal diet.

\begin{tabular}{lll}
\hline Analysis & Specifications & Results \\
\hline Mechanical mass & Max. 40\% $(\mathrm{m} / \mathrm{m})$ & $39.80 \%$ \\
\hline Wax & Max. $25 \%(\mathrm{~m} / \mathrm{m})$ & $2.59 \%$ \\
\hline Soluble solids & Min. 35\% $(\mathrm{m} / \mathrm{m})$ & $46.60 \%$ \\
\hline Oxidation activity & Max. 22 s. & $16 \mathrm{~s}$ \\
\hline Flavonoid expressed in quercetin & Min. 0,5\% $(\mathrm{m} / \mathrm{m})$ & $3.34 \%$ \\
\hline Minerals & Max. 5\% $(\mathrm{m} / \mathrm{m})$ & $3.77 \%$ \\
\hline Humidity & Max. 8\% $(\mathrm{m} / \mathrm{m})$ & $7.55 \%$ \\
\hline
\end{tabular}

(FCR) was calculated by dividing the feed intake by the number of eggs produced (EP) or by egg mass (EM).

Daily egg production; egg weight; egg specific gravity; eggshell percentage, weight and mineral composition; and yolk color were registered and evaluated daily. Six saline solutions, with densities of $1.060,1.070,1.080,1.090,1.100$ and 1.110, were used to evaluate egg specific gravity at a temperature of $15^{\circ} \mathrm{C}$ (Castelló et al., 1989). Saline solutions were calibrated using a hydrometer. Egg specific gravity was represented by the solution with the lowest density in which the egg emerged. Eggshell percentage was evaluated after the eggshells were dried at $60^{\circ} \mathrm{C}$ for three days, and calculated as the percentage of eggshell weight relative total egg weight (Castelló et al. (1989). Egg yolk color parameters L*(luminosity), $a *$ (redness) and $b *$ (yellowness) were determined three different points on the egg yolk surface using a color meter (Minolta ${ }^{\circledR} 410 R$, Konica Minolta, Wayne, U.S.A.). For the sensorial analysis, two eggs in each treatment were randomly selected and cooked for $10 \mathrm{~min}$ in boiling water, and were then offered to be appraised by 15 non-trained tasters.

Bird, cage, and roof surface temperature (Ts) were registered weekly, twice a day $(07 \mathrm{~h} 00 \mathrm{~min}$ and 13h00min), using a thermal imaging camera (Testo ${ }^{\circledR 875}$, Testo AG, Lenzkirch, Germany). The mean value of surface temperature was obtained by selecting 10 points within the thermal image applying the software (IRTesto ${ }^{\circledR}$ Testo AG, Lenzkirch, Germany), as shown in Figure 1. The adopted emissivity value for the tiles was 0.92 (Nääs et al., 2001). For calculating bird Ts, points were selected in feathered areas (neck and trunk) and featherless areas (comb, wattle and eyes), using the emissivity value of 0.94 for feathered areas and 0.95 for featherless areas, and the camera was placed at $0.72 \mathrm{~m}$ distant from the birds (Nääs et al., 2010). 
(a)

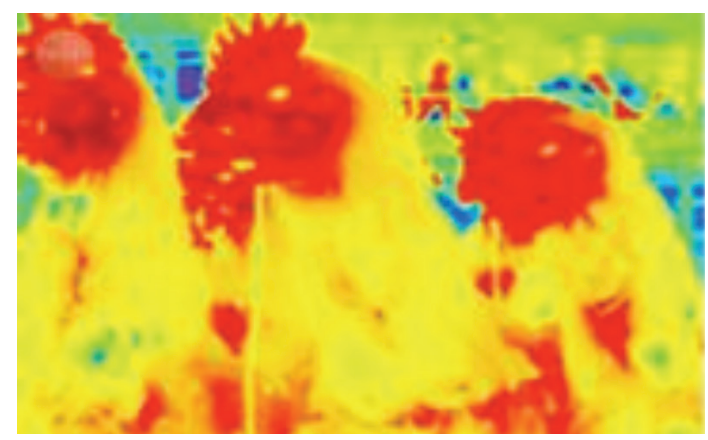

(b)

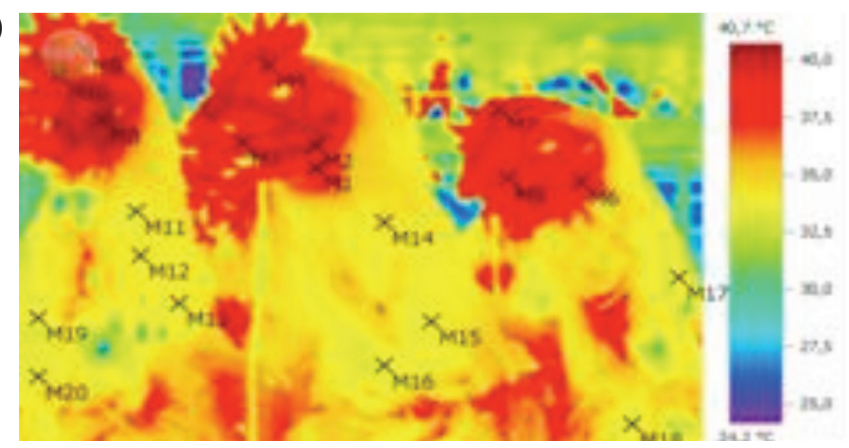

Figure 1. Thermal image of layers (a) and the points marked for calculating mean surface temperature (b).

Ambient temperature and relative humidity were recorded twice weekly at $07 \mathrm{~h} 00 \mathrm{~min}$ and $13 \mathrm{~h} 00 \mathrm{~min}$, using a digital temperature and relative humidity recorder (Amprobe, Everett, U.S.A.). Luminosity was measured once weekly using a digital lux meter (LX1010BS, Wensn, ShenZhen, China).

\section{Statistical analyses}

All data were subjected to analysis of variance (ANOVA), and the means were compared by the Tukey's test when normally distributed.

For the sensorial analysis, eggs were identified by numbers and the Multiple Comparison test was applied, and the tasters gave scores to the tested samples comparing them to the control sample (ABNT, 1995). Sensorial evaluation data were analyzed using the non-parametric test of Kruskall-Wallis. Data were processed using the software SAS (1996) adopting a probability level of $95 \%$.

\section{RESULTS AND DISCUSSION}

\section{Layer performance}

Feed intake was influenced by the treatment $(p<0.05$, Table 2): it decreased as dietary propolis inclusion level increased (T3 and T4). This reduction in food intake may be due to the astringent flavor of propolis. Egg production was also affected at the same proportion as feed intake as propolis dietary levels increased. This result differs from that found by Garcia et al. (2002) when analyzing the addition of canthaxanthin in layer diets. Galal et al. (2008) and Khojasteh \& Shivazad (2006) found that high concentrations of propolis in the diet improved performance. However, the levels of propolis added to the layer diets in those studies were lower than those evaluated in the present research.

Table 2 - Egg production (EP), feed conversion ratio per egg mass (FCREM), feed conversion ratio per egg produced (FCREP), and feed intake (FI) of layers fed different propolis levels.

\begin{tabular}{ccccc}
\hline Treatment & EP $(\%)$ & FCREM $(\mathrm{g})$ & FCREP $(\mathrm{g})$ & FI/hen $(\mathrm{g})$ \\
\hline T1 & $89.9 \mathrm{a}$ & $2.16 \pm 0.2 \mathrm{~b}$ & $94.75 \pm 0.0 \mathrm{~b}$ & $121.40 \pm 5.4 \mathrm{a}$ \\
\hline T2 & $85.0 \mathrm{ab}$ & $2.31 \pm 0.2 \mathrm{a}$ & $102.1 \pm 0.0 \mathrm{a}$ & $124.30 \pm 6.6 \mathrm{a}$ \\
\hline T3 & $82.0 \mathrm{ab}$ & $2.29 \pm 0.3 \mathrm{a}$ & $102.4 \pm 0.0 \mathrm{a}$ & $114.60 \pm 7.7 \mathrm{~b}$ \\
\hline T4 & $79.0 \mathrm{~b}$ & $2.22 \pm 0.2 \mathrm{~b}$ & $93.65 \pm 0.0 \mathrm{~b}$ & $105.00 \pm 5.7 \mathrm{~b}$ \\
\hline
\end{tabular}

Results are expressed as mean \pm standard deviation. Mean values within a column with no common letter are significantly different $(\mathrm{p}<0.05)$. $\mathrm{T} 1=$ control; $\mathrm{T} 2=1 \%$ propolis; $\mathrm{T3}=2 \%$ propolis; $\mathrm{T} 4=3 \%$ propolis inclusion in the diet

Feed conversion ratio per egg mass (FCREM) was influenced $(p<0.05)$ by the treatments, with better results obtained by the hens fed the $\mathrm{T} 1$ and $\mathrm{T} 4$ diets (Table 2). This result partially agrees with those obtained by Galal et al. (2008), who found that the feed conversion ratio of hens improved at high levels of propolis addition to the diet (100-150 mg/kg feed). However, in that study, the worst FCREM result was obtained in the control treatment, differing from the outcome of the present study. The effects of the addition of propolis to layer diets are still controversial. Silici et al. (2007) found a significant negative effect of different propolis doses on the weight gain of quails, while Ozkok et al. (2013) demonstrated that propolis supplementation in layer diets did not induce any adverse effect on performance, egg quality or survival rate, suggesting that different doses of propolis could be used in egg production.

\section{Egg quality}

Egg specific gravity was not affected by the treatments (Table 3, p>0.05). The values obtained in the present study are higher than those found by Silva et al. (2003), who, however, studied layers in the peak of production, layers were 55 weeks old in the present study. The treatments did not influence eggshell Ca content, which was higher than that found in the literature (Costa et al., 2008) and indicates that eggshell Ca content may not be influenced by the addition of propolis to layer diets. 
Table 3 - Egg specific gravity (EG, g/cm³ of egg), eggshell percentage (EP), eggshell calcium (Ca, mg/g) and phosphorus (P, $\mathrm{mg} / \mathrm{g}$ ) contents, and egg weight (EW, g) of layers fed different propolis levels.

\begin{tabular}{cccccc}
\hline Treatment & $\begin{array}{c}E G \\
\left(\mathrm{~g} / \mathrm{cm}^{3}\right)\end{array}$ & $\begin{array}{c}E P \\
(\%)\end{array}$ & $\begin{array}{c}\mathrm{Ca} \\
(\mathrm{mg} / \mathrm{g})\end{array}$ & $\begin{array}{c}P \\
(\mathrm{mg} / \mathrm{g})\end{array}$ & $\begin{array}{c}E G \\
(\mathrm{~g})\end{array}$ \\
\hline $\mathrm{T} 1$ & $1.09 \pm 0.0072$ & 9.64 & $378.25 \pm 4.72 \mathrm{~b}$ & $1.60 \pm 0.01 \mathrm{~b}$ & $66.06 \pm 3.31$ \\
\hline T2 & $1.09 \pm 0.0072$ & 9.72 & $385.00 \pm 0.82 \mathrm{a}$ & $1.62 \pm 0.01 \mathrm{a}$ & $65.73 \pm 3.75$ \\
\hline T3 & $1.09 \pm 0.0084$ & 9.88 & $377.00 \pm 1.83 \mathrm{~b}$ & $1.60 \pm 0.01 \mathrm{~b}$ & $64.65 \pm 4.32$ \\
\hline T4 & $1.09 \pm 0.0085$ & 9.55 & $375.75 \pm 0.96 \mathrm{~b}$ & $1.60 \pm 0.01 \mathrm{~b}$ & $65.22 \pm 4.08$ \\
\hline
\end{tabular}

Results are expressed as mean \pm standard deviation. Mean values within a column with no common letter are significantly different $(\mathrm{p}<0.05) . \mathrm{T} 1=\mathrm{control} ; \mathrm{T} 2=1 \%$ propolis; $\mathrm{T} 3=2 \%$ propolis; $T 4=3 \%$ propolis inclusion in the diet

There was no effect of the treatments on egg weight ( $p>0.05)$, as also found by Ting et al. (2011). However, the obtained values are higher than those found by Alves et al. (2007). Eggshell Ca and P contents were influenced by the treatments $(p<0.05)$, with the hens fed the diet with $1 \%$ presenting higher levels compared with those in the other treatments. However, this did not influence egg quality (Couto et al., 2008). Calcium is an important nutrient for birds, and it is an essential for metabolic functions and eggshell formation (Araújo et al., 2008).

Egg yolk color was affected by the treatments (Table 3; $p<0.05)$. Luminosity $\left(L^{*}\right)$ values were higher in eggs laid by hens fed propolis in their diet compared with the control treatment. On the other hand, redness $\left(a^{*}\right)$ value was higher in the yolks of T1 hens (control) relative to the other treatments, while yellowness $\left(b^{*}\right)$ values were lower in yolk of eggs laid by hens fed $3 \%$ propolis in the diet. The present results differ from those found by Garcia et al. (2002) who observed a direct correlation between the increase egg yolk color intensity as the product addition level increased. The effect of propolis in the hens' diet was reduced by the decrease in $a^{*}$ and $b$ * values and by the increase in $L^{*}$ values.

There was no effect of propolis dietary addition ( $p>0.05$ ) on egg weight (Table 4). However, average EW values of the present study were higher than those established by Viana et al. (2009), when evaluating the performance of layers fed enzymes to enhance nutrient absorption, which have the same effect attributed to propolis (Seven, 2008).

Sensorial analysis showed that tasters detected a moderate difference between the eggs laid by hens that were fed propolis compared with those laid by the control hens. This result suggests that the addition of propolis to layer feeds may affect consumers' acceptance. Hayat et al. (2010) showed that the addition of antioxidants to layer feeds did not increase the acceptance of egg by the tasters, similarly to the findings of the present study.

\section{Rearing ambient and surface temperature}

Average ambient temperature (Ta) recorded during the study was $27.9 \pm 4.9{ }^{\circ} \mathrm{C}$, and average relative humidity $(\mathrm{RH})$ was $77 \%$. These rearing conditions may induce heat stress, and are associated with high body surface temperature (Ts) values (Nääs et al., 2010). However, layer performance was not affected ( $p>0.05$ ). Average roof temperature was $56^{\circ} \mathrm{C}$.

Light intensity was, on average, $91 \mathrm{~lx}$ during the experiment, which is within the recommended interval (Freitas et al., 2010), and did influence the studied parameters.

Body Ts values $\left(\mathrm{T} 1: 32.15 \pm 1.96{ }^{\circ} \mathrm{C} ; \mathrm{T} 2: 31.79 \pm\right.$ $2.47{ }^{\circ} \mathrm{C} ; \mathrm{T3}: 32.15 \pm 2.53{ }^{\circ} \mathrm{C}$; $\left.\mathrm{T} 4: 31.66 \pm 3.01{ }^{\circ} \mathrm{C}\right)$

Table 4 - Mean egg weight $(g)$ and yolk luminosity $\left(L^{*}\right)$, red $\left(a^{*}\right)$ and yellow $\left(b^{*}\right)$ values in the eggs laid by layers fed different propolis levels.

\begin{tabular}{|c|c|c|c|c|}
\hline \multicolumn{4}{|c|}{ Yolk color } & \multirow[t]{2}{*}{ Egg weight } \\
\hline Treatment & $L^{*}$ & $a^{*}$ & $b^{*}$ & \\
\hline T1 & $64.45 \pm 1.22 b$ & $4.22 \pm 1.25 a$ & $37.06 \pm 0.87 a$ & $17.21 \pm 1.48$ \\
\hline $\mathrm{T} 2$ & $65.40 \pm 1.47 a$ & $2.86 \pm 1.16 \mathrm{~b}$ & $36.89 \pm 0.83 a$ & $16.86 \pm 1.54$ \\
\hline T3 & $65.65 \pm 1.62 a$ & $2.47 \pm 1.77 b$ & $36.74 \pm 0.82 a b$ & $17.20 \pm 1.54$ \\
\hline $\mathrm{T} 4$ & $65.71 \pm 1.25 a$ & $2.18 \pm 1.00 b$ & $36.37 \pm 0.73 b$ & $17.04 \pm 1.68$ \\
\hline
\end{tabular}

Results are expressed as mean \pm standard deviation. Mean values within a column with no common letter are significantly different ( $<<0.05)$. $T 1=$ control; $T 2=1 \%$ propolis; $T 3=2 \%$ propolis; $T 4=3 \%$ propolis inclusion in the diet 
were not influenced by the addition of propolis to the diet ( $p>0.05)$. This may indicate that the addition of propolis did not interfere with the heat exchange of the birds, in agreement with the findings of Viana et al. (2009). Mean body Ts varied according to rearing ambient temperature (Table 5) and was not affected by dietary propolis addition. Similar values are reported in the current literature when rearing ambient temperatures are around $40{ }^{\circ} \mathrm{C}$ (Mustaf et al., 2008; Nääs et al., 2010).

Table 5 - Mean surface temperature (Ts) of hens fed propolis in feathered areas (neck and trunk), and featherless areas (comb, wattle and eyes), in two periods of the day (morning and afternoon).

\begin{tabular}{lccc}
\hline \multirow{2}{*}{ Period } & \multirow{2}{*}{ Area } & \multicolumn{2}{c}{ Ts $\left({ }^{\circ} \mathrm{C}\right)$} \\
\cline { 3 - 4 } & & Diet with propolis & Diet without propolis \\
\hline \multirow{2}{*}{ Morning } & \multirow{2}{*}{ Feathered } & $27.95 \pm 3.46$ & $28.54 \pm 2.54$ \\
\cline { 3 - 4 } Afternoon & & $28.32 \pm 2.68$ & $29.48 \pm 2.39$ \\
\hline \multirow{2}{*}{ Morning } & \multirow{2}{*}{ Featherless } & $35.77 \pm 1.89$ & $35.76 \pm 1.38$ \\
\cline { 1 - 1 } Afternoon & & $36.13 \pm 1.65$ & $36.28 \pm 1.47$ \\
\hline
\end{tabular}

Results are expressed as mean \pm standard deviation.

\section{CONCLUSIONS}

The addition of propolis to the diet did not affect layer performance. However, it influenced egg quality, as determined by egg yolk color differences. Egg flavor was affected by the dietary addition of propolis, which reduced the acceptance of the eggs by tasters during the sensorial analysis. The amount of propolis to be added to layer feeds needs to be further evaluated.

\section{REFERENCES}

ABNT - Associação Brasileira de Normas Técnicas. NBR 13526 [cited 2010 dec. 20]. Rio de Janeiro; 1995. 9p. Available from: http://pt.scrib.com/ doc/1175761249590802/IALanalise-sensorial-de-alimentos-capitulo6Métodos-Físico-Químicos-para-Análise-de-Alimentos.

Alves SP, Silva IJO, Piedade SMS. Avaliação do bem-estar de aves poedeiras comerciais: efeitos do sistema de criação e do ambiente bioclimático sobre o desempenho das aves e a qualidade de ovos. Revista Brasileira de Zootecnia 2007;36(5):1388-394.

Araujo JAA, Silva, JHV, Amâncio ALL, Lima CB, Oliveira ERA. Fontes de minerais para poedeiras. Acta Veterinaria Brasílica 2008;2(3):53-60.

Castelló JAL, Pontes MP, González FF. Producción de huevos. Barcelona: Real Escuela de Avicultura; 1989. 367 p.

Chen YJ, Huang AC, Chang HH, Liao HF, Jiang CM, Lai LY, Chan JT, Chen YY, Chiang J. Caffeic acid phenanthryl ester, an antioxidant from propolis, protects peripheral blood mononuclear cells of competitive cyclists against hyperthermal stress. Journal of Food Science 2009;74(6):162167.

Costa FGP, Souza CJ, Goulart CC, Lima Neto RC, Costa JS, Walter Esfrain Pereira WE. Desempenho e qualidade dos ovos de poedeiras semipesadas alimentadas com dietas contendo óleos de soja e canola. Revista Brasileira de Zootecnia 2008;37(8):1412-1418.

Couto HP, Nery VLH, Fonseca JB, Chiquieri J, Carneiro LCR, Lombardi CT. Fontes alternativas de cálcio e fósforo para poedeiras comerciais. Revista Brasileira de Zootecnia 2008;37(8):1419-1423.

Freeman BM. The stress syndrome. World's Poultry Science Journal $1987 ; 43: 15-19$

Freitas HJ, Cotta JTB, Oliveira Al, Murgas LDS, Gewehr CE. Efeito de diferentes programas de iluminação para poedeiras semi-pesadas criadas em galpões abertos. Biotemas 2010;23(2):157-162.

Galal A, El-Motaal AAM, Ahmed AMH, Zaki TG. Productive performance and immune response of laying hens as affected by dietary propolis supplementation. International Journal of Poultry Science 2008 7(3):272-278

Garcia EA, Mendes AA, Pizzolante CC, Gonçalves HC, Oliveira RP, Silva MA. Efeito dos níveis de cantaxantina na dieta sobre o desempenho e qualidade dos ovos de poedeiras comerciais. Brazilian Journal of Poultry Science 2002;4(1):1-7.

Hayat Z, Cherian G, Pasha TN, Khattak FM, Jabbar MA. Sensory evaluation and consumer acceptance of eggs from hens fed flaxseed and two different antioxidants. Poultry Science 2010;89(10):2293-2298.

Isa brown-guía general de manejo de ponedoras comerciales [cited 2013 aug]. 2009. 10 p. Available from: http://www.isapoultry.com/es-es/ products/isa/isa-brown/ /media/Files/ISA/Different\%20languages/ Spanish/Products/CS/ISA/Guia\%20de\%20Manejo\%20General\%20 de\%20ponedoras\%20comerciales\%20ISA\%20Brown.ashx.

Khojasteh SS, Shivazad M. The effect of diet propolis supplementation on Ross broiler chicks performance. International Journal of Poultry Science 2006;5(1):84-88.

Kimoto N, Masao HH, Kawabe M, Satoh T, Hideki M, Shira T. Postinitiation effects of a supercritical extract of propolis in a rat twostage carcinogenesis model in female F344 rats. Cancer Letters 1999;147:221-227

Mutaf S, Şeber KN, Firat MZ. Surface wetting and its effect on body and surface temperatures of domestic laying hens at different thermal conditions. Poultry Science 2008;87(12):2441-2450.

Nääs IA, Sevegnani, KB, Marcheto FG, Espelho JCC, Menegassi V, Silva IJO. Avaliação térmica de telhas de composição de celulose e betumem, pintadas de branco, em modelos de aviários com escala reduzida. Engenharia Agrícola 2001;21(2):121-126

Nääs IA, Romanini CEB, Neves DP; Nascimento GR, Vercellino RA. Broiler surface temperature distribution of 42 day old chickens. Scientia Agricola 2010; 67(5):497-502.

NRC. Nutrient requirements of poultry. $9^{\text {th }}$ ed. Washington: National Academy Press; 1994. p.19-34.

Nieva Moreno MI, Isla MI, Cudmani NG, Vattuone MA, Sampietro AR. Screening of antibacterial activity of Aimacha del Valle (Tucumán, Argentina) propolis. Journal Ethnopharmacology 1999;68(1-3):97-102.

Ozkok D, Iscan KM, Silici S. Effects of dietary propolis supplementation on performance and egg quality in laying hens. Journal of Animal and Veterinary Advances 2013;12(2):269-275

SAS Institute. SAS: User's guide: Stat: Version 6.11. Cary; 1996. 83 p.

Seven PT. The effects of dietary Turkish propolis and vitamin $\mathrm{c}$ on performance, digestibility, egg production and egg quality in laying hens under different environmental temperatures. Asian-Australasian Journal of Animal Science 2008;21(8):1164-1170 
Silici S, Karabacak M, Balci, E, Cankaya S. Effect of the propolis on the performance and carcass characteristics of growing quail. Mellifera 2007;7(13/14):20-26.

Silva JHV, Jordao Filho J, Silva EL. Efeito do alho (Allium sativum Linn.), probiótico e virginiamicina antes, durante e após o estresse induzido pela muda forçada em poedeiras semipesadas. Revista Brasileira de Zootecnia 2003;32(6):1697-1704.

Ting S, Yeh HS, Lien T. Effects of supplemental levels of hesperetin and naringenin on egg quality, serum traits and antioxidant activity of laying hens. Animal Feed Science and Technology 2011;163(1):59-66.
Viana MTS, Albino LFT, Rostagno HS, Silva EA, Messias RKG, Pereira JPL. Efeito do uso de enzimas sobre o desempenho e metabolismo de poedeiras. Revista Brasileira de Zootecnia 2009;38(6):1068-1073.

Wang BJ, Lien YH, Yu ZR. Supercritical fluid extractive fractionation-study of the antioxidant activities of propolis. Food Chemistry 2003;86:237243. 